\title{
Verdict: Hwang's human stem cells were all fakes
}

\section{SEOUL}

The results are in. The university committee looking into scientific misconduct in the laboratory of South Korean cloner Woo Suk Hwang announced on 10 January that his 2004 claim to have cloned a human embryo was fake. But his Afghan hound Snuppy is a real done.

The announcement finally confirms the gravest suspicions of Hwang's work with humans. There are two papers in which Hwang's group claimed to clone human cells - a 2004 artide that describes the first cloned embryo and derivation of a stem-cell line from it (W. S. Hwang et al. Science 303, 1669-1674; 2004), and a 2005 article that claims the establishment of eleven 'patient-specific' stem-cell lines (W. S. Hwang et al. Science 308, 1777-1783; 2005). Both have turned out to be complete and deliberate fakes.

${ }^{\alpha}$ Such an act is nothing other than deception of the scientific community and the public at large," condudes Myung Hee Chung of Seoul National University (SNU), who headed the committee.

With the 2005 paper already discredited in the panel's interim report (see Nature 439, 8; 2005), Chung's statement focused on the 2004 paper. DNA fingerprinting tests carried out by three laboratories found that the genetic material of the supposedly cloned human cell line, NT-1, did not match that of the donor. Nor did it match any of the stem-cell lines from the in vitro fertilization (IVF) embryos of MizMedi Hospital, which were the source for the faked data in the 2005 paper.

Further investigation revealed that mitochondrial DNA from the cell line matched one of the egg donors, but the DNA inside the cells' nuclei varied at several locations. The committee concluded that the line was derived by parthenogenesis - where the single set of chromosomes in an egg develop as if it were fertilized. The images and data in the paper that showed perfect matches were fabricated.

The committee also found that Hwang worked with a staggering number of eggs 2,061 from 129 women - despite claiming to have used only 242 eggs for the 2004 study and 185 for the 2005 study.

The findings are a huge setback for therapeutic cloning - the idea that cloned embryos could be used as a source of patient-matched stem cells to replace damaged tissues in a range of diseases. Even using numbers of human eggs of which other researchers can only dream, Hwang's team was unable to derive such stem cells, and the field is now left with no evidence that it is possible in humans at all (see Nature, 438, 1056-1059; 2005).

The committee did find that Hwang succeeded in cloning human embryos to the blastocyst stage, from which stem cells can be derived. But the success rate was just $10 \%$, and they were "in poor condition. The only other group to have some uccess, Alison Murdoch's team at the University of Newcastle upon Tyne, UK, has cloned just a single blastocyst (M. Stojkovic et al. Reprod. BioMed. Online 11, 226-231; 2005).

It is possible to create embryonic stem-cell

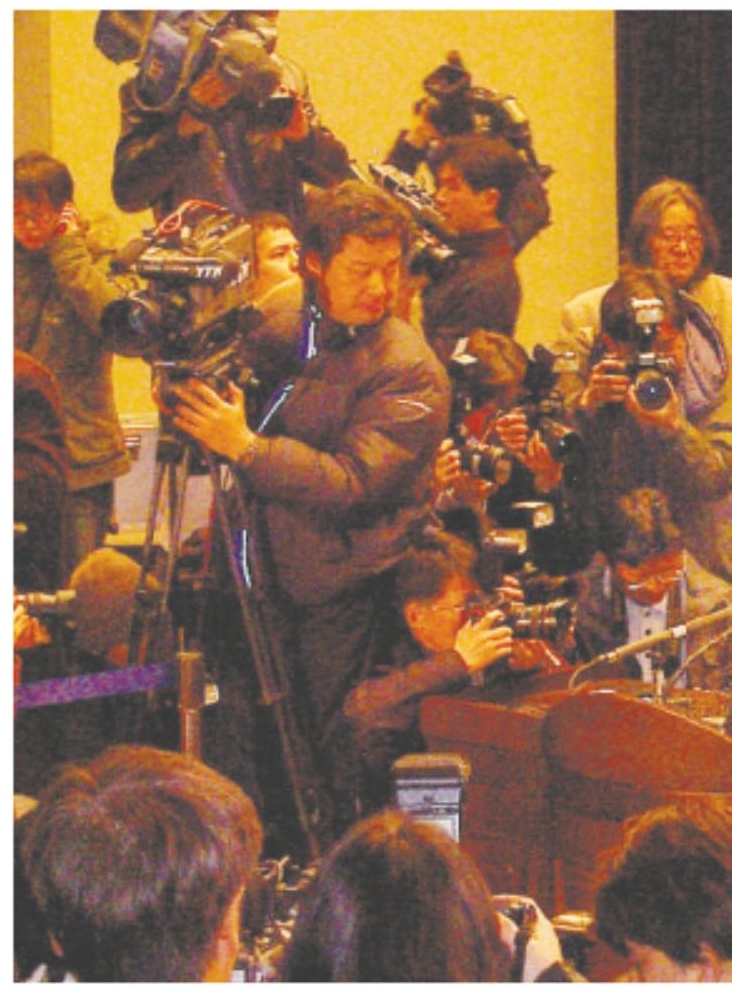

lines, insists Kevin Eggan, a researcher in the field at Harvard University, Massachusetts. But no one will venture a guess as to when it might be accomplished. "There are many unknowns," says Eggan. "We don't know how many eggs will be needed and we don't know how many women will step forward to contribute."

Ethical transgressions in the way Hwang got his eggs - he seems to have coerced junior researchers into donating - have stim-

\section{French research chief quits over reforms}

\section{PARIS}

Bernard Meunier, president of

France's basic-research agency, the CNRS, resigned on

5 January. The move brings to a headsimmering internal tensions over the future of the 26,000-member body.

The CNRS has declined to comment on the resignation, apartfrom issuing a short statement by Meunier. In it, he makes public his disagreement over the reform plans of the agency's director-general, mathematician Bernard

Larrouturou. In principle, the president defines the general goals of CNRS policy and the director-generalcarries them through, but in practice the latter holds the reins of power.

The reforms came into force on 1 January. They are meant to encouragemultidisciplinarity, wealth creation, the development of labs outside Paris, and tighterlinks with French universities. The structural reforms are due to be completed later this year by a 'strategic plan' that will lay out future policies in more detail.

As a result of the reform, the CNRS's eight existing departments have been regrouped into four broad departments - life sciences, chemistry, humanities, and maths and physics - and two 'cross-cutting' departments - engineering and the environment, and sustainable development.

Meunier, a chemist, regards Larrouturou's reforms as unnecessary management interference that he believes will weaken science at the agency. He thinks that the new configuration of departments would complicate rather than simplify matters, with laboratories often belonging toseveral different departments atonce, and he questions how the cross- 
